\title{
Genetic Identification of Victims in a Bus Fire by the Use of NoorGIS Software
}

\author{
Miri A*, Habibi S, Bahmani H, Kiani E, Mohammadi A and Tavallaie M \\ Human Genetics Research Center, Baqiyatallah University of medical sciences, Tehran, Iran
}

*Corresponding author: Miri A, Human Genetics Research Center, Baqiyatallah University of medical sciences, Tehran, Iran, Fax: +98 2186034943, Tel: +98 2186034943, E-mail: alimiri1391@gmail.com; rsr.miri@bmsu.ac.ir

Citation: Miri A, Habibi S, Bahmani H, Kiani E, Mohammadi A, et al. (2018) Genetic Identification of Victims in a Bus Fire by the Use of NoorGIS Software. J Forensic Crime 2: 203

Article history: Received: 21 April2018, Accepted: 26 June 2018, Published: 29 June 2018

\begin{abstract}
During 2015, a fatal incident happened in Iran. A terrible explosion was happened by a bus fire and in this incident 11 victims burned. Some of the victims could be identified with their medical case history and their external signs. But six victims due to severe burns were identified with genetic analysis. For genetic identification was used 16 plex identifier kit. The identified victims were from different families and for that reason parents and children of victims were used for genetic analysis. Result of that analysis identified all of the victims with the highest amount of paternity index (PI). For DNA matching used novel software that called NoorGIS. Likelihood ratio (LR) and Probability of Paternity (PP) test were performed using Familias software for efficiency evaluation NoorGIS.
\end{abstract}

Keywords: DNA Analysis; Short Tandem Repeat (STR); Paternity Index (PI)

\section{Introduction}

An explosion happened by a bus fires at $24 \mathrm{~km}$ of Damghan Road in Iran. In this incident 11 victims burned. Only five victims could be identified from medical history and their fingerprints [1,2]. Samples of parents, children and siblings were used for genetic analysis and among them there were a parent with lost child and six children as family's samples.

Genetic identification of individuals in forensic assemblies is known as an exact molecular method. For example using PowerPlex16 and AmpFeSTR Identifiler were 1 in $10^{18}$ (with applying 16 loci Random Match Probability is $7.2 \times 10^{-19}$ ) in different incidents [3]. In this method, it is possible to use molecular indicators like STRs, mtDNA and Single Nucleotide Polymorphisms (SNPs) [4-6]. Considering multiple loci simultaneously produces a single and unique combination for everyone. Those loci can be considered with different compositions in commercial kits but one common case is 15 Short Tandem Repeat (STR) loci including D2S1338, D16S539, D13S317, TH01, D3S1358, CSF1PO, D7S829, D21S11, D8S1179, D5S818, D18S51, TPOX, VWA, D19S433, FGA and amelogenin as one sexuality indicator [3]. In Disaster Victim Identification (DVI), there are substantial numbers of genetic data and other information that must be analyzed. For genetic analysis been used some tools like: MDKAP, DNA-View, PATPCR, CEPOL software and CODIS [7]. In this research, results analyzed by novel software that called NoorGIS. In this software Paternity Index (PI), Combined Paternity Index (CPI) and posterior probability are calculated according to allelic frequency of Iranian [8].

\section{Material and Methods}

Initially, to acquire genetic information of samples collected from victims and their family members. A centimeter of samples were collected. Then 17 blood samples from families of victims were collected to the genetic laboratory.

\section{DNA Extraction}

DNA purification from biological samples can be accomplished using different methods [9-12]. In this study was used RGDE method for DNA extraction [13].

For rapid genomic DNA extraction method pour $500 \mu \mathrm{l}$ of blood or $0.5 \mathrm{~g}$ of fresh tissue into a $1.5 \mathrm{ml}$ microfuge tube and add 1000 $\mathrm{ml}$ of cell lysis buffer. Shake microfuge tube gently, and then centrifuge it for $2 \mathrm{~min}$ at $6000 \mathrm{rpm}$. Remove and discard supernatant 
and repeat this step two or three more times according to the sample. Then to that white sediment nucleu lysis buffer was added and it was completely mixed with buffer using mixed peptide sediment. Then using salting out method some proteins and wastes go out of the samples.

The next step was supplying DNA with water by adding cold and absolute alcohol to the samples. In that case, alcohol molecules were connected to the DNA which makes DNA heavy and its string visible.

Then applying centrifuge makes DNA sediment and after making it dry, DNA samples were dissolved in TE buffer.

\section{Quality Control}

This step was done by light absorption using nanophotometer machine and Agarose electrophoresis gel for samples. After DNA purification and before performing PCR, for quantity control of samples used nanophotometer machine with IMPLAN model. That machine uses ultra-violet spectrometer to search for very small DNAs, RNAs and proteins. That machine calculates different absorption wavelengths of DNA, RNA and protein. It is possible to perform quality control for samples using electrophoresis method for 15 minutes with $1 \%$ of Agarose gel in a tank with 0.5 molar TBE and $110 \mathrm{~W}$ voltages. DNA yield calculated $4.36 \pm 2.53$ $\mu \mathrm{g}$ and light absorption A260/A280 ratio was $1.91 \pm 0.13$ for appropriate quality control of samples.

PCR

This step was done by applying PowerPlex16 AmpFeSTR Identifiler kit which is the product of Applied Biosystems Company. After quality control, PCR was used to amplify the number of STR sequences. Reaction components for this step are 1ng of DNA, specific primers, Master Mix and Taq polymerase enzyme. Steps involved in thermocycler machine's activity are denaturation, Annealing and Extension. In denaturation, temperature was increased to $950{ }^{\circ} \mathrm{C}$. In Annealing process, the temperature was reduced to 550 ${ }^{\circ} \mathrm{C}$ such that primer was attached to the DNA sample. Finally, in Extension step, the temperature was again increased to $720{ }^{\circ} \mathrm{C}$ and Taq enzyme starts replication. Those three steps were usually repeated for 25-35 times depending on different applications they may have. Then the reaction was ended at $4{ }^{\circ} \mathrm{C}$ temperature. This step is called PrePCR. After that PostPCR is a step that applies PrePCR product to add HiDiFormamid and size standard. Then samples were placed for 5 minutes in $950^{\circ} \mathrm{C}$ temperature that makes DNA single-stranded. Then the temperature was lowered to $0{ }^{\circ} \mathrm{C}$ so that HiDi could fix single-stranded DNA. The next step was placing samples to specific plate of genetic analysis machine.

\section{Sample's profiles}

This step was done with 3130xl genetic analyzer machine from Applied Biosystems Company. That machine can apply Argon laser with maximum stimulation of 488 and 514 nanometers to specify STR locus.

\section{Data analysis}

Initially, samples were analyzed using GeneMapper ID software [14,15]. After obtaining genetic information for individuals and to further analyze the data, in addition to genetic software and genetic information banks, specific native software with ability to search data and compare genetic and individual information is necessary [16,17]. For the mentioned event with high amount of genetic data, NoorGIS software was used for genetic analysis and genetic computation specially Paternity Index (PI) and Combined Paternity Index (CPI) $[18,19]$. Also Familias software was used for likelihood ratio analysis in cases when the amount of genetic comparison was specified [20].

\section{Results}

Genetic profiles of samples from victims and their family members were prepared in the laboratory using AmpFeSTR Identifiler. Then the results for unknown victims and 16 STR loci from family members were compared. Table 1 shows the number of victims and their families' samples and their relatives.

Samples of parents, children and siblings were used for genetic analysis and among them there were a parent with lost child and six children as family's samples.

\begin{tabular}{|c|c|c|c|c|}
\hline Number of victims & $\begin{array}{c}\text { Parents as victims' } \\
\text { families }\end{array}$ & Single parent & Child & $\begin{array}{c}\text { Other } \\
\text { relationships }\end{array}$ \\
\hline 11 & 1 & 2 & 6 & 1 \\
\hline
\end{tabular}

Table 1: Number of victims and their families' samples

DNA matching has done according Table 2. In two cases the comparisons were completely and other cases had an accurate DNA matching. 


\begin{tabular}{|c|c|c|c|c|c|c|c|c|c|c|c|c|c|c|c|c|c|c|}
\hline & \multicolumn{2}{|c|}{ Mother } & \multicolumn{2}{|c|}{ Child1 } & \multicolumn{2}{|c|}{ Child2 } & \multicolumn{2}{|c|}{ Father } & \multicolumn{2}{|c|}{ Mother } & \multicolumn{2}{|c|}{ Child } & \multicolumn{2}{|c|}{ Father } & \multicolumn{2}{|c|}{ Mother } & \multicolumn{2}{|c|}{ Child2 } \\
\hline Loci & & & 110 & 725 & & 726 & & & & 293 & & 0294 & & & 110 & 737 & 110 & 2726 \\
\hline Csf1po & 12 & 11 & 11 & 11 & 11 & 11 & 11 & 12 & 11 & 12 & 11 & 12 & 13 & 10 & 11 & 10 & 11 & 10 \\
\hline D135317 & 13 & 11 & 13 & 13 & 13 & 11 & 11 & 11 & 11 & 12 & 11 & 11 & 11 & 11 & 11 & 8 & 8 & 8 \\
\hline D165539 & 11 & 11 & 12 & 11 & 11 & 13 & 11 & 12 & 9 & 9 & 9 & 12 & 13 & 9 & 10 & 9 & 13 & 9 \\
\hline FGA & - & - & 23 & 23 & 23 & - & - & 27 & 22 & 23 & 22 & 27 & 23 & 19 & 25 & 18 & 19 & 18 \\
\hline D75820 & 11 & 9 & 12 & 11 & 11 & 9 & 8 & 11 & 8 & 12 & 8 & 11 & 8 & 7 & 11 & 8 & 8 & 7 \\
\hline D18551 & 17 & 12 & 19 & 17 & 17 & 19 & 12 & 22 & 18 & 20 & 14 & 20 & 13 & 13 & 16 & 14 & 16 & 13 \\
\hline D21511 & 32.2 & 32.2 & 32.2 & 29 & 29 & - & - & 30.2 & 29 & 32.2 & 29 & 30.2 & 30.2 & 30.2 & - & - & 30.2 & 30 \\
\hline D251338 & 19 & 18 & 25 & 18 & 18 & 25 & 18 & 24 & 20 & 20 & 20 & 24 & 21 & 19 & 23 & 20 & 20 & 19 \\
\hline D195433 & 14 & 13 & 14 & 13 & 13 & 13 & 12 & 16 & 13 & 13 & 13 & 14.2 & 15.2 & 15 & 13.2 & 13 & 15 & 13 \\
\hline D3511358 & 16 & 15 & 15 & 14 & 14 & 16 & 16 & 17 & 17 & 18 & 17 & 17 & 16 & 15 & 18 & 16 & 16 & 15 \\
\hline D55818 & 13 & 13 & 13 & 12 & 12 & 13 & 12 & 13 & 11 & 11 & 11 & 12 & 11 & 10 & 12 & 11 & 11 & 11 \\
\hline D851179 & 14 & 13 & 13 & 13 & 13 & 14 & 13 & 13 & 10 & 12 & 10 & 13 & 13 & 12 & 14 & 10 & 14 & 12 \\
\hline TH01 & 9 & 9 & 9 & 9 & 9 & 9 & 7 & 9 & 7 & 8 & 8 & 9 & 9.3 & 9.3 & 9 & 6 & 9.3 & 9 \\
\hline TPOX & 8 & 8 & 11 & 8 & 8 & 8 & 8 & 8 & 8 & 8 & 8 & 8 & 9 & 8 & 8 & 8 & 9 & 8 \\
\hline VWA & 17 & 17 & 17 & 16 & 16 & 17 & 17 & 17 & 16 & 18 & 14 & 16 & 17 & 17 & 17 & 16 & 17 & 16 \\
\hline
\end{tabular}

\begin{tabular}{|c|c|c|c|c|c|c|c|c|c|c|c|c|c|c|c|c|}
\hline & \multicolumn{2}{|c|}{ Father } & \multicolumn{2}{|c|}{ Child } & \multicolumn{2}{|c|}{ Sibling } & \multicolumn{2}{|c|}{ Father } & \multicolumn{2}{|c|}{ Child } & \multicolumn{2}{|c|}{ Child } & \multicolumn{2}{|c|}{ Father } & \multicolumn{2}{|c|}{ Mother } \\
\hline Loci & \multicolumn{2}{|c|}{115} & \multicolumn{2}{|c|}{114} & \multicolumn{2}{|c|}{11002727} & \multicolumn{2}{|c|}{118} & \multicolumn{2}{|c|}{112} & \multicolumn{2}{|c|}{116} & \multicolumn{2}{|c|}{11002740} & \multicolumn{2}{|c|}{11002739} \\
\hline Csflpo & 12 & 10 & 11 & 10 & 11 & 10 & 11 & 10 & 12 & 11 & 11 & 11 & 11 & 11 & 11 & 11 \\
\hline D135317 & 12 & 12 & 14 & 12 & 12 & 8 & 12 & 11 & 12 & 12 & 12 & 12 & 12 & 8 & 12 & 8 \\
\hline D165539 & 12 & 9 & 12 & 12 & 12 & 10 & 9 & 9 & 12 & 9 & 12 & 11 & 12 & 11 & 12 & 12 \\
\hline FGA & 24 & 23 & 24 & 23 & 24 & 23 & 23 & 21 & 21 & 21 & 24 & 24 & 24 & 20 & 24 & 23 \\
\hline D75820 & 10 & 8 & 11 & 10 & 12 & 8 & 12 & 11 & 11 & 11 & 11 & 11 & 12 & 11 & 11 & 11 \\
\hline D18551 & 17 & 13 & 17 & 12 & 17 & 13 & 15 & 15 & 18 & 15 & 17 & 17 & 17 & 16 & 17 & 15 \\
\hline D21511 & 30 & 28 & 32.2 & 30 & 31.2 & 30 & 32.2 & 32.2 & 32.2 & 30 & 31 & 30 & 31 & 30 & 30 & 30 \\
\hline D251338 & 20 & 17 & 20 & 18 & 19 & 17 & 22 & 18 & 18 & 18 & 25 & 23 & 23 & 22 & 25 & 19 \\
\hline D195433 & 14 & 12 & 14 & 12 & 14 & 13 & 15.2 & 13 & 15.2 & 13 & 14 & 14 & 14 & 13 & 14 & 14 \\
\hline D3511358 & 17 & 17 & 17 & 16 & 19 & 17 & 17 & 14 & 15 & 14 & 17 & 15 & 17 & 15 & 17 & 15 \\
\hline D55818 & 12 & 12 & 13 & 12 & 14 & 12 & 11 & 9 & 11 & 9 & 12 & 12 & 12 & 11 & 13 & 12 \\
\hline D851179 & 13 & 10 & 14 & 13 & 14 & 13 & 14 & 12 & 12 & 12 & 15 & 14 & 14 & 14 & 15 & 12 \\
\hline TH01 & 9.3 & 6 & 9.3 & 9 & 9.3 & 6 & 9.3 & 9.3 & 9.3 & 9 & 8 & 7 & 7 & 6 & 9 & 8 \\
\hline TPOX & 9 & 8 & 11 & 9 & 11 & 8 & 10 & 10 & 10 & 10 & 9 & 8 & 9 & 9 & 10 & 8 \\
\hline VWA & 17 & 17 & 17 & 17 & 17 & 17 & 19 & 18 & 18 & 17 & 17 & 15 & 15 & 14 & 18 & 17 \\
\hline
\end{tabular}

Table 2: DNA matching for different cases with STR markers of AmpFESTR Identifiler kit.

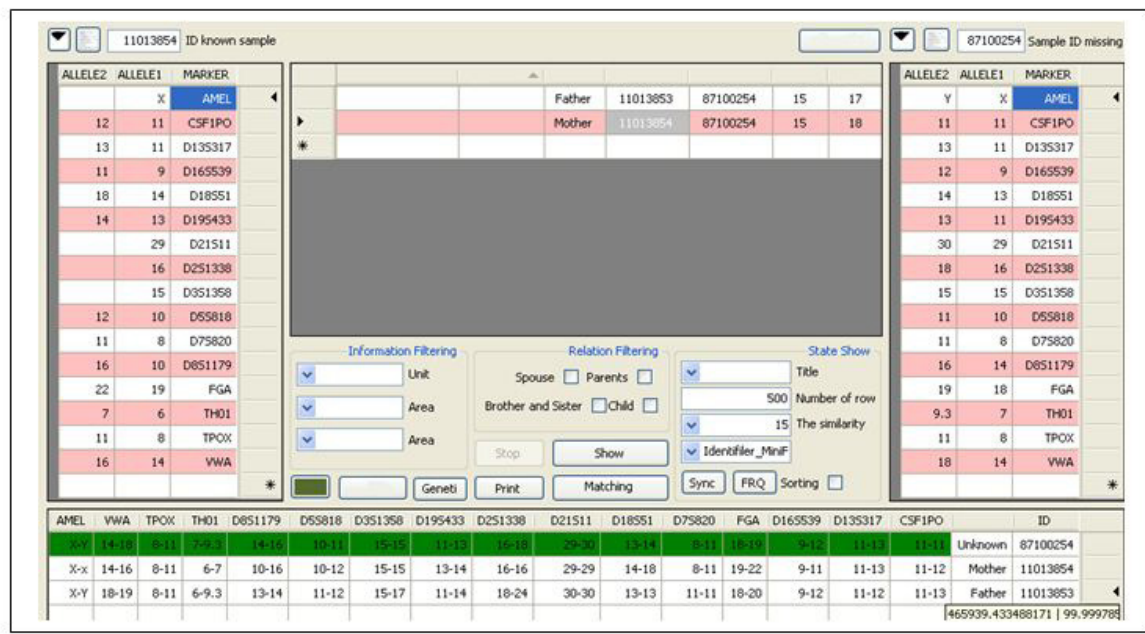

Figure 1: An example figure of profiles' genetic comparison by NoorGIS 
Last step for genetic comparison was performed by calculating PI, as reported earlier [21]. For those individuals Paternity Index (PI) was calculated considering parent one child condition. All genetic profiles from corpses and relatives of victims were compared in a separate project using NoorGIS software. Figure 1 illustrates hypothetical genetic comparison in which marker and allele similarities were demonstrated. Amount of PI was changed between the lowest amount and the exact amount of PI (when genetic similarity is completed). For example the amount of LR for genetic comparison study is equal to 465939 and posterior probability is 0.9997 . Those values could confirm the result of the genetic comparisons.

After saving the genetic profiles in NoorGIS software, amount of genetic comparisons between victims and their families have been estimated in two separate victims and families' bank. Figure 1 illustrates the amount and quality of that genetic similarity between an unknown victim and his parent.

\section{Discussion}

All genetic comparison process between victims and their families were performed in the minimum time and the results were reported. Some genetic information from individuals before death could be very useful in making genetic identification process faster however, for no genetic background was available from victims. Genetic analysis is exact scientific methods that can be important for genetic identification of victims in some events especially when ante mortem data are not present.

It may happen one or two STR from genetic profiles not similar which can be the result of mutation in that locus (22). For example, mutation rate in vWA locus is equal to $0.2 \%$. For the result of genetic comparison from NoorGIS software, likelihood ratio (LR) test was performed using Familias software. The amount of LR for a population under study has been valuable. For example the amount of LR for genetic comparison study is equal to 46420760 and posterior probability is 0.9999999 . Those values could confirm the result of the genetic comparisons.

By using NoorGIS software, it was possible to study and compare the genetic relationship between individuals and a given population, investigate personal genetic information, process obtained genetic information by employing genetic similarities and information. Also, processing capabilities was enhanced to achieve favorable outcomes in the genetic identification.

\section{References}

1. Winkelmann A, Tessmann B (2018) Identification and return of a skull from Tasmania in the Berlin anatomical collection. Anthropologischer Anzeiger; Bericht uber die biologisch-anthropologische Literatur 75: 39-47.

2. Rivalderia N, Gutierrez-Redomero E, Alonso-Rodriguez C, Dipierri JE, Martin LM (2017) Study of fingerprints in Argentina population for application in personal identification. Sci Justice 57: 199-208.

3. Butler JM (2006) Genetics and genomics of core short tandem repeat loci used in human identity testing. J Forensic Sci 51: 253-65.

4. Westen AA, Matai AS, Laros JF, Meiland HC, Jasper M, et al. (2009) Tri-allelic SNP markers enable analysis of mixed and degraded DNA samples. Forensic Sci Int Genet 3: 233-41.

5. Divne AM, Allen M (2005) A DNA microarray system for forensic SNP analysis. Forensic Sci Int 154: 111-21.

6. Ossowski A, Diepenbroek M, Kupiec T, Bykowska-Witowska M, Zielinska G, et al. (2016) Genetic Identification of Communist Crimes' Victims (1944-1956) Based on the Analysis of One of Many Mass Graves Discovered on the Powazki Military Cemetery in Warsaw, Poland. J Forensic Sci 61: 1450-5.

7. Alonso A, Martín P, Albarrán C, Garcí P, Simón D, et al. (2005) Challenges of DNA profiling in mass disaster investigations. Croat Med J 46: 540-8.

8. Shepard EM, Herrera RJ (2006) Iranian STR variation at the fringes of biogeographical demarcation. Forensic Sci Int 158: 140-8.

9. Baeta M, Nunez C, Cardoso S, Palencia-Madrid L, Herrasti L, et al. (2015) Digging up the recent Spanish memory: genetic identification of human remains from mass graves of the Spanish Civil War and posterior dictatorship. Forensic Sci Int Genet 19: 272-9.

10. Schwark T, Modrow JH, Steinmeier E, Poetsch M, Hasse J, et al. (2015) The auditory ossicles as a DNA source for genetic identification of highly putrefied cadavers. Int J Legal Med 129: 457-62.

11. Schwark T, Heinrich A, von Wurmb-Schwark N (2011) Genetic identification of highly putrefied bodies using DNA from soft tissues. Int J Legal Med 125: 891-4. 12. Allouche M, Hamdoum M, Mangin P, Castella V (2008) Genetic identification of decomposed cadavers using nails as DNA source. Forensic Sci Int Genet 3: 46-9.

13. Ali SM, Mahnaz S, Mahmood T (2008) Rapid genomic DNA extraction (RGDE). Forensic Sci Int Genet 1: 63-5.

14. Marjanović D, Hadžić Metjahić N, Čakar J, Džehverović M, Dogan S, et al. (2015) Identification of human remains from the Second World War mass graves uncovered in Bosnia and Herzegovina. Croat Med J 56: 257-62.

15. Zupanič Pajnič I, Podovšovnik Axelsson E, Balažic J (2014) Slovenian population data for five new European Standard Set Short tandem repeat loci and SE33 locus. Croat Med J 55: 14-8.

16. Kling D, Egeland T, Pinero MH, Vigeland MD (2017) Evaluating the statistical power of DNA-based identification, exemplified by 'The missing grandchildren of Argentina. Forensic Sci Int Genet 31: 57-66.

17. Wright K, Mundorff A, Chaseling J, Forrest A, Maguire C, et al. (2015) A new disaster victim identification management strategy targeting "near identification-threshold" cases: Experiences from the Boxing Day tsunami. Forensic Sci Int 250: 91-7.

18. Gjertson DW, Brenner CH, Baur MP, Carracedo A, Guidet F, et al. (2007) ISFG: Recommendations on biostatistics in paternity testing. Forensic Sci Int Genet 1: $223-31$. 
19. Miri A, Rabdost Motlagh M, Tavallaie A, Tavallaie M (2014) Genetic Identification by NoorGIS Software to Identify Martyrs in Military Accidents. J Mil Med 15: 267-71.

20. Egeland T, Mostad PF, Mevåg B, Stenersen M (2000) Beyond traditional paternity and identification cases: selecting the most probable pedigree. Forensic Sci Int 110: 47-59.

21. Hill CR (2012) Capillary electrophoresis and 5-channel LIF detection of a 26plex autosomal STR assay for human identification. Methods Mol Biol 830: 17-29.

22. Lai L, Shen X, Han L, Chen D, Hu J (2015) Genetic study of the Penta E locus and identification of rare alleles. Zhonghua Yi Xue Yi Chuan Xue Za Zhi 32: 657-60. 